Original Research Article

\title{
Role of nicotine in depression through dopaminergic mechanism
}

\author{
Rahul R. Bhalsinge*, Rajbhoj Satkar, Sayan Das, Shraddha Yadav, Shah A. S., P. S. Worlikar
}

Department of Pharmacology, Dr. D.Y. Patil Medical College, Pimpri, Pune, Maharashtra, India

Received: 18 January 2017

Accepted: 25 February 2017

*Correspondence to:

Dr. Rahul R. Bhalsinge,

Email:

rahulbhalsinge@gmail.com

Copyright: () the author(s), publisher and licensee Medip Academy. This is an openaccess article distributed under the terms of the Creative Commons Attribution NonCommercial License, which permits unrestricted noncommercial use, distribution, and reproduction in any medium, provided the original work is properly cited.

\begin{abstract}
Background: There are interesting reports in the literature indicating relationship of smoking /nicotine and depression. Smokers use nicotine to treat depression. The objectives of present study were to evaluate the role of nicotine in depression through Dopaminergic mechanism by using haloperidol induced catalepsy model in rats and to estimate Dopamine level in brain of depressed rats after nicotine and imipramine.

Methods: Dopaminergic activity was evaluated in haloperidol induced catalepsy in rats. Levels of dopamine in normal as well as in depressed rats brain was estimated using fluorimetric method. The study treatment were administered as follows - Vehicle (s.c.), Imipramine (i.p.) - 7days, Nicotine (subcutaneous), Nicotine (inhalation) were administered in a dose of $1 \mathrm{ml} / \mathrm{kg}, 10 \mathrm{mg} / \mathrm{kg}, 0.4 \mathrm{mg} / \mathrm{kg}, 0.2 \mathrm{mg} / \mathrm{kg}$ respectively.

Results: In haloperidol induced catalepsy model, vehicle treated group showed cataleptic effect starting at 1 hour and lasting for 6 hours. Nicotine administered by subcutaneous route significantly reduced cataleptic score as compared to vehicle treated group till 6 hours. Nicotine administered by inhalation route reduced cataleptic score up to 6 hours compared with that of vehicle. Catalepsy score in nicotine (inhalation) group was significantly less as compared to nicotine (subcutaneous) at all time points period except 2 hours. Isolation induced hyperactivity model was used to induce depression in rats. Dopamine levels in rats after isolation were significantly less as compared to normal rats (before isolation). After isolation, dopamine levels in imipramine treated rats were significantly higher as compared to vehicle treated group. After isolation, dopamine levels were significantly high in both groups i.e., nicotine (subcutaneous) and nicotine (inhalation). Imipramine (7 days) and single dose of nicotine (inhalation) showed comparable results with normal dopamine level i.e. before isolation rats.

Conclusions: Nicotine has increased dopaminergic activity as evident by reversal of haloperidol induced catalepsy. Dopamine level reduced in depressed rats. Dopamine brain levels were increased, when depressed rats were treated with Imipramine (i.p.), nicotine (s.c.), nicotine(inhaled). Single dose nicotine given by inhalation route has produced significant antidepressant action comparable to that of seven days' treatment of standard antidepressant drug imipramine in rats. In rats, nicotine by both routes i.e subcutaneous and inhalational increased dopaminergic activity.
\end{abstract}

Keywords: Catalepsy, Dopamine, Depression, Haloperidol induced catalepsy, Isolation induced hyperactivity, Nicotine

\section{INTRODUCTION}

There are interesting reports in the literature indicating relationship of smoking/nicotine and depression. ${ }^{1}$ Smokers use nicotine to treat depression. It has also been observed that the chances of stopping smoking are less in depressed patients. ${ }^{2}$ Recently, interest has turned to the role of dopamine in depression. This is based on a wide body of preclinical data.

There is clinical evidence identifying low concentrations of homovanillic acid (HVA, a metabolite of DA) in the cerebrospinal fluid (CSF) and plasma of depressed patients. ${ }^{3,4}$ The same authors have studied and published 
an article regarding antidepressant effect of nicotine in isolation induced hyperactivity model. Therefore, this study is planned with the objectives:

- To evaluate dopaminergic mechanism in the action of nicotine in depression.

- To estimate brainlevels of Dopamine in depressed rats.

\section{METHODS}

Experimental protocol was approved by Institutional

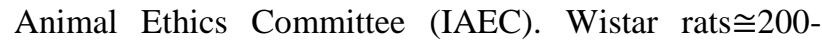
250gm (male/female) housed in polypropylene cages (single rat/cage) were used. ( $\mathrm{n}=10$ in each group). Dopaminergic mechanism was evaluated by using haloperidol induced catalepsy model. Study treatment in each group:

- Group 1: Vehicle control $1 \mathrm{ml} / \mathrm{kg}$ s.c.

- Group 2: Nicotine $0.4 \mathrm{mg} / \mathrm{kg}$ s.c.

- Group 3: Nicotine $0.2 \mathrm{mg} / \mathrm{kg}$ inhalational.

Haloperidol was injected in a dose of $1.5 \mathrm{mg} / \mathrm{kg}$ intraperitoneally. After haloperidol injection, nicotine was injected by subcutaneous or inhalational route in a dose of $0.4 \mathrm{mg} / \mathrm{kg}$ and $0.2 \mathrm{mg} / \mathrm{kg}$ respectively. Catalepsy score in study treatment groups was measured from $0 \mathrm{hr}$ to $6 \mathrm{hrs}$. This was compared with the control group.

Catalepsy following the injection of haloperidol was measured every hour over for 6hours by using the standard bar test. Forelimbs of a rat were placed on a horizontal bar of diameter $1.5 \mathrm{~cm}$ and at the height of $7 \mathrm{~cm}$. Length of time, the rat maintained this position on horizontal bar was measured in seconds.

Catalepsy induced by haloperidol in vehicle treated group was considered as control. ${ }^{5-8}$ The scoring was done as described by Green et al (Table 1).

Table 1: Scoring described by Green et al.

\begin{tabular}{|llll|}
\hline $\begin{array}{l}\text { Total time of } \\
\text { catalepsy (sec) }\end{array}$ & Score & $\begin{array}{l}\text { Total time of } \\
\text { catalepsy (sec) }\end{array}$ & Score \\
\hline $0-10$ & 0 & $121-150$ & 03 \\
\hline $11-30$ & 0.5 & $151-180$ & 3.5 \\
\hline $31-60$ & 01 & $181-210$ & 04 \\
\hline $61-90$ & 1.5 & $211-240$ & 4.5 \\
\hline $91-120$ & 02 & $240-\alpha$ & 05 \\
\hline
\end{tabular}

\section{Biochemical estimation of brain dopamine levels}

Study treatment in each group contains normal rats and depressed rats.

\section{Normal rats}

- $\quad$ Group 1: Vehicle (1 $\mathrm{ml} / \mathrm{kg}$ s.c.)

\section{Depressed rats}

- Group 2: Vehicle (1 $\mathrm{ml} / \mathrm{kg}$ s.c.)

- Group 3: Imipramine (10mg/kg i.p.) for 7 consecutive days.

- Group 4: Nicotine $(0.4 \mathrm{mg} / \mathrm{kg} \mathrm{sc})-$ Single dose

- Group 5: Nicotine (0.2mg/kg inhalation)-Single dose

Isolation induced hyperactivity model was used to induce depression in rats. Study treatment administered during isolation period.

\section{Extraction}

Before extraction of rat brain tissue, rats were isolated for 15 days. After seven days' treatment of imipramine andsingle dose administration of nicotine, rats were sacrificed by cervical dislocation (According to CPCSEA guidelines, this method is acceptable for euthansia of laboratory animals). Whole brain was dissected and the tissue was homogenized in $0.1 \mathrm{ml} \mathrm{HCl}$-butanol $(0.85 \mathrm{ml}$ $37 \% \mathrm{HCl}$ in 1 litre n-butanol for spectroscopy) for 1 minute in a glass homogenizer.

The sample was then centrifuged for $10 \mathrm{~min}$ at $2000 \mathrm{~g}$. An aliquot of the supernatant phase $(0.08 \mathrm{ml})$ was removed and added to an Eppendorf reagent tube (vol. $1.5 \mathrm{ml}$ ) containing $0.2 \mathrm{ml}$ heptane (for spectroscopy) and $0.025 \mathrm{ml} \mathrm{HCl} 0.1 \mathrm{M}$. After $10 \mathrm{~min}$ of vigorous shaking, the tube was centrifuged under the same conditions as above in order to separate the two phases, and the overlaying organic phase was discarded. The aqueous phase $(0.02 \mathrm{ml})$ was then taken for DA assay. All steps were carried out at $0^{\circ 96}$.

\section{Dopamine assay}

Braindopamine levels were estimated by fluorimetric method as described by Margret and Walter. The assay represents a miniaturization of the trihydroxyindole method

\section{Statistical analysis}

The results were expressed as total catalepsy score. Statistical significance was determined by Kruskal Wallis test followed by Dunn test, using Primer of Biostatistics. $p<0.05$ was considered to be statistically significant. ${ }^{9}$ Data was analyzed by one-way analysis of variance (ANOVA) followed by Tukey test, using Primer of Biostatistics. $\mathrm{P}<0.05$ was considered as significant.

\section{RESULTS}

Dopaminergic mechanism by using haloperidol induced catalepsy model. In this study, vehicle treated group had catalepsy score of 5 from 1 hour to 6 hours. Nicotine administered by subcutaneous route significantly reduced 
catalepsy score as compared to vehicle treated group from 1 hour to 6 hours $(\mathrm{p}<0.05)$.

Table 2: Catalepsy score in nicotine treated rats.

\begin{tabular}{|c|c|c|c|}
\hline \multicolumn{4}{|c|}{ Haloperidol induced catalepsy score $(\mathrm{N}=10)$} \\
\hline $\begin{array}{l}\text { Time } \\
\text { (Hrs) }\end{array}$ & $\begin{array}{l}\text { Vehicle(s.c.) } \\
\text { (Median) }\end{array}$ & $\begin{array}{l}\text { Nicotine(s.c.) } \\
\text { (Median) }\end{array}$ & $\begin{array}{l}\text { Nicotine(inhal.) } \\
\text { (Median) }\end{array}$ \\
\hline 0 & 0 & 0 & 0 \\
\hline 1 & 5 & $1 * *$ & $0.5 \bullet \bullet \#$ \\
\hline 2 & 5 & $2 * *$ & $1.25 \bullet \bullet$ \\
\hline 3 & 5 & $3 * *$ & $2 \bullet \bullet \#$ \\
\hline 4 & 5 & $3 * *$ & $2 \bullet \bullet \# \#$ \\
\hline 5 & 5 & $3.5 * *$ & $2 \bullet \bullet \#$ \\
\hline 6 & 5 & $3.5^{* *}$ & $2.25 \bullet \bullet \#$ \\
\hline
\end{tabular}

Nicotine administered by inhalation route reduced catalepsy score of haloperidol up to $6 \mathrm{hrs}$ compared with that of vehicle $(\mathrm{p}<0.05)$. As compared to subcutaneous, inhalational nicotine had significantly lower catalepsy score at all time points except at 2 hours (Table 2).

Effect of study treatment on brain dopamine levels are depicted in Table 3. Brain dopamine levels in Normal rats was $128.35 \mathrm{ng} / \mathrm{g}$ of brain tissue. Levels of dopamine significantly reduced to $30.08 \mathrm{ng} / \mathrm{g}$ in brain tissue in depressed rat $(\mathrm{p}<0.001)$. Dopamine levels in the vehicle treated group in depressed rats were compared with the three-study treatment group i.e. imipramine, nicotine (sc) and nicotine (inhalation) after isolation.

Table 3: Results of Brain DA level after study treatment in isolated rats.

\begin{tabular}{|c|c|c|}
\hline Groups & Treatment & $\begin{array}{l}\text { Brain Dopamine levels } \\
\text { in depressed rats }\end{array}$ \\
\hline 1 & $\begin{array}{l}\text { Vehicle control } \\
\text { (Normal rats) }\end{array}$ & $128.35 \pm 19.69$ \\
\hline 2 & $\begin{array}{l}\text { Vehicle control } \\
\text { (Depressed rats) }\end{array}$ & $30.08 \pm 8.34$ \#\#\# \\
\hline 3 & $\begin{array}{l}\text { Imipramine } \\
\text { (10mg/kg) - } 7 \text { days } \\
\text { (Depressed rats) }\end{array}$ & $107.93 \pm 13.44 * * *$ \\
\hline 4 & $\begin{array}{l}\text { Nicotine }(0.4 \mathrm{mg} / \mathrm{kg} \\
\text { s.c.) SD (Depressed } \\
\text { rats) }\end{array}$ & $47.83 \pm 9.73 * *$ \\
\hline 5 & $\begin{array}{l}\text { Nicotine }(0.2 \mathrm{mg} / \mathrm{kg} \\
\text { inhal.) SD } \\
\text { (Depressed rats) }\end{array}$ & $97.52 \pm 13.98 * * *$ \\
\hline \multicolumn{3}{|c|}{$\begin{array}{l}\text { SD }=\text { Single dose } \\
\# \# \#=\text { Vehicle control (before isolation) Vs Vehicle cont } \\
(\text { after isolation })(\mathrm{p}<0.001) \\
\text { After isolation } \\
* * *=\text { Vehicle Vs Imipramine }(10 \mathrm{mg} / \mathrm{kg})-7 \text { days }(\mathrm{p}<0.001) \\
* *=\text { Vehicle Vs SD Nicotine }(0.4 \mathrm{mg} / \mathrm{kg} \text { s.c. })(\mathrm{p}<0.001) \\
* * *=\text { Vehicle Vs SD Nicotine }(0.2 \mathrm{mg} / \mathrm{kg} \text { inhal. })(\mathrm{p}<0.001)\end{array}$} \\
\hline
\end{tabular}

Dopamine levels were significantly increased in imipramine treated groups to $107.93 \mathrm{ng} / \mathrm{g}$ of brain tissue. This increase was highly significant as compared to the dopamine levels in vehicle treated groups in depressed rats. Difference between dopamine levels of vehicle and imipramine treated groups was highly significant ( $p$ $<0.001)$.

Dopamine levels in depressed rats were found to be significantly higher in Nicotine administered subcutaneous $(47.83 \mathrm{ng} / \mathrm{g})$ of brain tissues compared to vehicle treated depressed rats. Similarly, Dopamine levels increased significantly in depressed rats treated with nicotine inhalational $(97.52 \mathrm{ng} / \mathrm{g})$ of brain tissues as compared to vehicle treated depressed rats. Nicotine administered by subcutaneous and inhalational route showed significantly increased brain dopamine levels as compared to vehicle treated rats after isolation i.e. in depressed rats.

Dopamine levels of nicotine treated by subcutaneous route were significantly less as compared to dopamine levels of imipramine treated rats $(\mathrm{p}<0.001)$. Dopamine level in group receiving Nicotine by inhalational route was comparable with imipramine group.

Seven days' treatment with imipramine and single dose of nicotine administered by inhalational route in depressed rats showed comparable results with dopamine levels in normal rats.

\section{DISCUSSION}

Haloperidol causes extra pyramidal symptoms by inhibiting $\mathrm{D}_{2}$ receptors and the drugs increasing release of DA inhibit development of these symptoms. ${ }^{10,11}$ Popik P reported antidepressant activity after two weeks of chronic treatment with imipramine and after one week of treatment with combination of nicotine and imipramine, in apomorphine induced hyperactivity model. This effect could be due to nicotine's adaptive action on dopaminergic system and imipramine's action on noradrenergic system. ${ }^{12}$ In present study, nicotine given by both subcutaneous and inhalational routes inhibited haloperidol induced catalepsy. Isolation induced hyperactivity method was used to induce depression in rats. ${ }^{13}$ Dopamine levels in depressed rats were significantly increased in imipramine group. It was found that dopamine levels in groups receiving nicotine by both route i.e. subcutaneous and inhalational were increased as compared to vehicle treated depressed rats.

The study also showed that inhalational nicotine increased dopamine in depressed rat brain, but lesser in magnitude as compared to imipramine. Increased levels of dopamine in rat brain substantiate the findings of our study confirming the effect of imipramine and nicotine. Other studies with subcutaneous implantation of nicotine showed a delayed antidepressant action in learned 
helplessness models. The results of our study are consistent with the same. ${ }^{14,15}$

Inhalational nicotine reduced catalepsy at all time points indicating that inhalational nicotine increased levels of dopamine for a longer time in rat brain. A single dose of inhalational nicotine showed comparable result to that of seven-day treatment with imipramine. This is of clinical importance since at present no satisfactory drug treatment is available for an acute episode of depression.

\section{CONCLUSION}

The present study shows that brain dopamine levels are low in rats with depression. Nicotine increased brain dopamine levels in these rats. Thus, antidepressant effect of nicotine observed by the present authors may be exerted by increasing brain dopamine levels.

\section{ACKNOWLEDGEMENTS}

Estimation of brain monoamines and GABA levels in rat were conducted in Department of Pharmacology, Poona College of Pharmacy, Bharati Vidyapeeth Deemed University, Pune-38 under the supervision of Dr. S.N. Bodhankar.

Funding: No funding sources Conflict of interest: None declared

Ethical approval: The study was approved by the Institutional Ethics Committee

\section{REFERENCES}

1. Barroso MG. Depression: Clinical definition and case histories. The International J Transpersonal Studies. 2003;22:89-99.

2. Markou A, Thomas RK, George FK. Neurobiological similarities in depression. Neuropsychopharmacology. 1998;18(3):135-74.

3. Baldessarini RJ. Drug therapy of depression and anxiety disorders. In Brunton LL, Lazo JS, Parker KL, editors. Goodman and Gilman's the pharmacological basis of therapeutics. $11^{\text {th }} \mathrm{Ed}$. New York: McGraw-Hill, Medical Publishing Division. 2006:429-59.

4. Debattista C. Antidepressant agents. In.Chapter 30. Katzung BG, Masters SB, Trevor AJ. Basic and clinical Pharmacology. 11 $1^{\text {th }}$ Ed. McGraw-Hill, Medical Publishing Division. 2009:509-30.
5. Khisti RT, Mandhane SN, Chopde CT. Haloperidolinduced catalepsy: a model for screening antidepressants effective in treatment of depression with Parkinson's disease. Indian Exp Biol. 1997;35(12):1297-301.

6. Dunlop BW, Nemeroff CB. The role of dopamine in the pathophysiology of depression. Arch Gen Psychiatry. 2007;64:327-37.

7. Mathur R. Antidepressants. In: Drug Screening Methods, Gupta, S.K. (Ed.). Chapter 8. Jaypee Brothers, New Delhi, India, ISBN-13: 9788180613975; 2004:76-82.

8. Green AR, Bloomfield MR, Attwewill CK, Costain DW. Electroconvulsive shock reduces the cataleptogenic effect of both haloperidol and arecoline in rats. Neuropharmacology. 1979;18:44751.

9. Rao KV. Biostatistics- A manual of statistical methods for use in health, nutrition and anthropology. Jaypee Brothers, 2nd Ed. 2007:226-60.

10. Abdel-salam OM, Baiuomy AR. Effect of different drugs influencing monoamine neurotransmission on haloperidol-induced catalepsy in mice. Turk J Med Sci. 2007;37(6):333-8.

11. Abin-Carriquiry JA, Urbanavicius J, Scorza C, Rebolledo-Fuentes M, Wonnacott S, Cassels BK. Increase in locomotor activity after acute administration of the nicotinic receptor agonist 3bromocytisine in rats. Eur J Pharmacol. 2010;634:8994.

12. Popik P, Krawczyk M, Koz T, Nalepa I. Nicotine produces antidepressant like actions: behavioral and neurochemical evidence. Eur J Pharmacol. 2005;515:128-33.

13. Potdar VH, Kibile SJ. Evaluation of antidepressantlike effect of citrus maxima leaves in animal models of depression. Iran J Basic Med Sci. 2011;14(5):47883.

14. Skolnick P. Antidepressants for the new millennium. Eur J Pharmacol. 1999;375(1-3):31-40.

15. Semba J, Matake C, Yamada S, Nankai M, Toru M. Antidepressant like effects of chronic nicotine on learned helplessness paradigm in rats. Bio Psychiatry. 1998;43(5):389-91.

Cite this article as: Bhalsinge RR, Satkar R, Das S, Yadav S, Shah AS, Worlikar PS. Role of nicotine in depression through dopaminergic mechanism. Int J Basic Clin Pharmacol 2017;6:864-7. 